\title{
Dye-sensitized Solar Cell Based on Flower-like ZnO Nanoparticles as Photoanode and Natural Dye as Photosensitizer
}

\author{
G.P. Agus Sumiarna, Irmansyah, Akhiruddin Maddu*
}

\author{
Biophysics Division, Department of Physics, Bogor Agricultural University, Bogor 16680 Indonesia
}

\author{
(Received 20 February 2016; revised manuscript received 09 June 2016; published online 21 June 2016)
}

\begin{abstract}
In this paper was reported the fabrication of dye-sensitized solar cell utilizing flower-like $\mathrm{ZnO}$ nanoparticle as photoanode and natural dye (anthocyanin) extracted from Lampeni (Ardisia humilis Vahl) fruit as photosensitizer. Anthocyanin dye extracted from Lampeni (Ardisia humilis Vahl) fruit shows a wide range of absorption spectra covering from $400 \mathrm{~nm}$ to $600 \mathrm{~nm}$, which suitable for application as sensitizer in dye-sensitized solar cell. Flower-like $\mathrm{ZnO}$ was synthesized by precipitation method from mixed solution of zinc acetate dihydrate and $\mathrm{KOH}$. X-ray diffraction analysis of $\mathrm{ZnO}$ was found a hexagonal structure with lattice parameters $a=b=3.25 \AA$ and $c=5.21 \AA$, while average crystal size (ACS) was found $23.403 \mathrm{~nm}$. The observation by SEM shows a flower-like structure arranged from $\mathrm{ZnO}$ nanorods. Optical absorption spectra of $\mathrm{ZnO}$ shows a strong absorption under $350 \mathrm{~nm}$, and sharp absorption transition occurs around $350 \mathrm{~nm}$ from which the bandgap energy of $\mathrm{ZnO}$ was determined. Using Tauc plot method, bandgap energy of $\mathrm{ZnO}$ was found $3.2 \mathrm{eV}$. The assembled solar cell has energy conversion efficiency about of $0.03 \%$ with fill factor of 0.25 and maximum power output of $12.8 \mu \mathrm{Watt}$.
\end{abstract}

Keywords: Anthocyanin dye, Ardisia humilis Vahl, DSSC, Flower-like ZnO.

DOI: 10.21272/jnep.8(2).02012

PACS numbers: 85.00, 85.60. - q

\section{INTRODUCTION}

Solar cell is a device that is capable to convert solar energy to electrical energy directly. Photovoltaic effect is the basic of the process of solar energy conversion to electricity by photovoltaic cell or solar cell utilizing semiconductor junction. Silicon solar cell is a form of conventional solar cell nowadays. Its base material is limited by the high-expense technology. To solve this problem, it needs improvement to the other forms of solar cell. Nowadays, one of the technological developments of solar cell is a nanoparticle layer attached with dye-sensitizer developed by Gratzel in 1991, called dyesensitized solar cell (DSSC) [1]. This cell consists of a nanoparticle semiconductor layer as photoelectrode soaked in a fotosensitizer to attach dye molecule as electron donor. It was a simple and low-cost process so that solar power technology is very interesting to be expanded as an alternative energy.

Nanostructured $\mathrm{ZnO}$ has widely been used as photoelectrode in dye-sensitized solar cell [2-4]. $\mathrm{ZnO}$ is well known as $n$-type extrinsic semiconductor having wide band gap of $3.37 \mathrm{eV}$ [5]. Nanorod, nanofiber and nanowire structures of $\mathrm{ZnO}$ were mostly often utilized as photoanode in DSSC development [6-9].

In DSSC, dye functions as an electron donor to the semiconductor layer excited when the dye molecules exposed by the sunlight. Recently, many dyes have been used as a photosensitizer in DSSC either synthetic or natural dyes. Synthetic dyes generally uses ruthenium-complex based metal organic, this one is quite expensive. Meanwhile, natural dye extracted from parts of plants such as leaves, flowers or fruit, can be used as photosensitizer in DSSC instead of expensive synthetic dye [10-12]. Natural dye is color substances or pigment from a plant which can be used as fotosensitizer in DSSC including chlorophyll, carotene, anthocy- anin or pycocyanin. Unlimited natural dye can be explorated from tropical sea and forest, as like in Indonesia.

In this research we used flower-like $\mathrm{ZnO}$ nanoparticle as photoanode and natural dye as photosensitzer to fabricate a dye-sensitized solar cell. This research uses anthocyanin dye extracted from the skin of fresh Lampeni (Ardisia humilis Vahl) fruit as photosensitizer to assembly DSSC. Lampeni (Ardisia humilis Vahl) fruit was an endemic plant in tropical forest of Indonesia. Lampeni (Ardisia humilis Vahl) fruit has dark red color. Anthocyanin dye from Lampeni (Ardisia humilis Vahl) fruit has not been used as a natural sensitizer in dye-sensitized solar cell. Also, there are no more report utilizing flower-like $\mathrm{ZnO}$ nanoparticle as photoanode in DSSC.

\section{EXPERIMENTAL}

\subsection{Synthesis of ZnO Nanoparticle}

Flower-like $\mathrm{ZnO}$ nanoparticles was synthesized by precipitation method at $90{ }^{\circ} \mathrm{C}$. Firstly, $2.195 \mathrm{~g}$ zinc acetate was dissolved in $100 \mathrm{~mL}$ aquadest and stirred for one hour. Potassium hydroxide with concentration of $3 \mathrm{M}$ in $10 \mathrm{~mL}$ aquadest was added to the solution and continuously stirred for 5 hours. The suspension then was heated on a hotplate for 3 hours at temperature $90{ }^{\circ} \mathrm{C}$ without being stirred. It was next centrifuged to take the powder product and then was washed with distilled water in an ultrasonic water bath. The powder was then dried at temperature $60^{\circ} \mathrm{C}$ for 3 days, after that it was heated at temperature $200{ }^{\circ} \mathrm{C}$ for 24 hours in a furnace. Characterization was conducted using $\mathrm{X}$ ray Diffraction (XRD) to determine crystal stucture and Scanning Electron Microscope (SEM) to observe its morphology.

\footnotetext{
*maddu3@gmail.com
} 


\subsection{Preparation of $\mathrm{ZnO}$ Film}

Amount of $0.02 \mathrm{~g}$ of $\mathrm{ZnO}$ powder was made paste with $3 \%$ acetic acid solution [13]. Following that, it was coated on slide glass by casting method and then dried using hair dryer. The film would be characterized by optical spectrospcopy to know its optical properties including optical bandgap of $\mathrm{ZnO}$.

\subsection{Extraction of Anthocyanin Dye}

Anthocyanin dye was extracted by maceration from $25 \mathrm{~g}$ of the fresh Lampeni (Ardisia humilis Vahl) fruit skin, soaked in a solvent consisted of $50 \mathrm{~mL}$ of methanol, $10 \mathrm{~mL}$ of acetic acid, and $50 \mathrm{~mL}$ of distilled water for 24 hours in a dark room. After that, anthocyanin was measured its $\mathrm{pH}$ value using $\mathrm{pH}$ stripes indicator.

\subsection{Preparation of $\mathrm{ZnO} /$ Anthocyanin Hybrid Film}

$\mathrm{ZnO}$ /anthocyanin hybrid film was made by mixing $\mathrm{ZnO}$ powder and anthocyanin powder with the ratio $1: 1$. After that, it was coated onto slide glass substrate by casting method. This film would be characterized its optical property to know interaction between $\mathrm{ZnO}$ nanoparticle with anthocyanin dye.

\subsection{Optical Characterization}

$\mathrm{ZnO}$ film, anthocyanin extract solution, and $\mathrm{ZnO} /$ anthocyanin hybrid film were characterized their optical properties using UV-Vis spectrophotometer. Optical absorption of $\mathrm{ZnO}$ film was measured from which its optical bandgap could be determined using Tauc plot [13]. Optical absorption of anthocyanin dye also was measured to find its optical absorption range. Also, the optical absorption of $\mathrm{ZnO} /$ anthocyanin hybrid film was measured to provide information about interaction between $\mathrm{ZnO}$ and anthocyanin dye.

\subsection{Preparation of Electrolyte}

Electrolyte solution was made by dissolving $0.8 \mathrm{~g} \mathrm{KI}$ in $10 \mathrm{~mL}$ acetonitrile solution that was then stirred evenly. It was next added $0,127 \mathrm{~g} \mathrm{I}_{2}$ in the solution until those three substances dissolved completely. It was then storaged in a closed bottle.

\subsection{Assembly of Solar Cell}

Solar cell was assembled by making paste of $0,15 \mathrm{~g}$ $\mathrm{ZnO}$ powder added by $3 \%$ acetic acid and three drops Triton X-100 and then grounded by mortar. The paste was then coated on ITO glass which has been made the pattern of $2 \times 2 \mathrm{~cm}^{2}$ using Doctor Blade method. After the paste dried, it was then heated at $250{ }^{\circ} \mathrm{C}$ on a hotplate and then soaked in anthocyanin solution for 5 minutes. The surface was then covered by another ITO glass which was coated by carbon from graphite pencil on its conductive surface. Into the cell was added 2 drops of $\mathrm{KI} / \mathrm{I}_{2}$ electrolyte solution and then measured the solar cell performance.

\section{RESULTS AND DICUSSION}

\subsection{Structure and Morphology of ZnO Nanopar- ticle}

Crystal structure of $\mathrm{ZnO}$ was studied by X-Ray diffraction (XRD) analysis. Difraction pattern of $\mathrm{ZnO}$ powder as seen at Fig. 1 shows all of the peaks which appears belong of $\mathrm{ZnO}$ crystal. All peaks show that this result is appropriate with the hexagonal wurzite $\mathrm{ZnO}$ crystal structure. Three first peaks at $2 \theta$ angle of $31^{\circ}$, $34^{\circ}$ and $36^{\circ}$ corresponding to the diffraction planes of (100), (002), and (101), respectively, indicates growing the $\mathrm{ZnO}$ crystal occurs perfectly. This result is comparable with the results by Bhakat, et.al [14]. This diffraction pattern has shown the compatibility with JCPDS data no. 36-1451 as reported by Shah et al. [15].

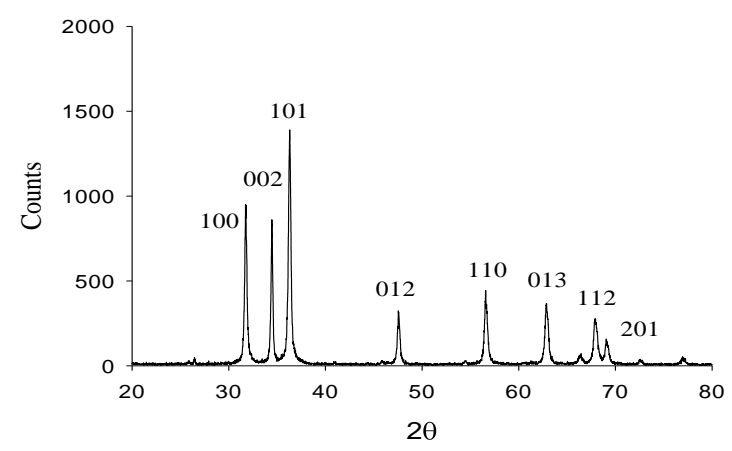

Fig. 1 - Diffraction pattern of $\mathrm{ZnO}$ nanoparticle

Lattice parameters were calculated using Cohen method. Parameters $a$ and $c$ were found $3.255 \AA$ and $5.219 \AA$, respectively. This result is close to the one which was conducted by Park, et al. [16], for lattice parameters are 3.195 and 5.202 Á, meanwhile research conducted by Vishnoi, et. al. [17], with parameter $a$ is $3.207 \AA$ and parameter $c$ is $5.136 \AA$.

Crystal size was represented by widening of diffraction peaks. The average crystal size (ACS) can be determined by using Scherrer equation (1), as follows

$$
\sigma=\frac{k \lambda}{\beta \cos \theta}
$$

where $\sigma$ is the average crystal size (ACS), $k$ is a constant of $0.9, \lambda$ is the wavelength of X-ray source $(1,54059 \AA), \beta$ is the full-width half maximum (FWHM) of each peak, and $\theta$ is difraction angle. Calculation result using Scherrer method was found the average crystall size is $23.403 \mathrm{~nm}$, indicating the $\mathrm{ZnO}$ is nanocrystalline.

Surface morphology of $\mathrm{ZnO}$ nanoparticle was studied using scanning electron microscope (SEM). Fig. 2 shows a clearly image of surface morphology of $\mathrm{ZnO}$ with magnification of 10.000 times. In the SEM image looks nano-sized $\mathrm{ZnO}$ rods are arranged in groups to form a flower-like structure. $\mathrm{ZnO}$ nanorods are arranged in such a way to form separate grains in the form of flower-like structure. This image suggests that the process and precursors as well as the conditions of growing have been going well. 


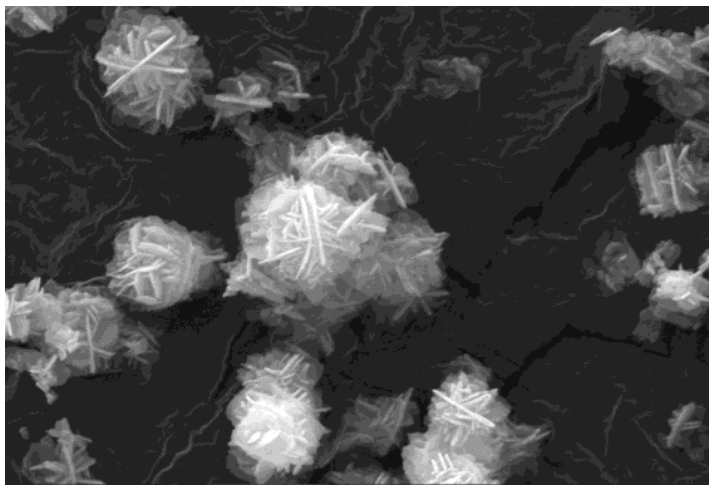

Fig. 2 - SEM image of flower-like $\mathrm{ZnO}$ nanoparticle

\subsection{Optical Properties of $\mathrm{ZnO}$ Nanoparticle}

Optical characteristic of $\mathrm{ZnO}$ was measured using UV-Vis spectrophotometer. Fig. 3 shows absorption spectra of $\mathrm{ZnO}$ film coated on slide glass substrate. The $\mathrm{ZnO}$ film strongly absorbs UV spectrum under wavelength $350 \mathrm{~nm}$, and almost not absorb the spectrum over the wavelength $350 \mathrm{~nm}$. Absorption edge can be identified clearly at about wavelength $350 \mathrm{~nm}$ which is the optical transition occurs.

To determine the optical bandgap of $\mathrm{ZnO}$ film, it used Tauc Plot method by making relationship between absorption coefficient of $\mathrm{ZnO}$ towards foton energy $(h v)$. Optical bandgap of $\mathrm{ZnO}$ film can be estimated fundamentally based on its transition of absorption spectra by using a relation as follows

$$
(\alpha h v)^{1 / n}=A\left(h v-E_{g}\right)
$$

where $a$ is absorption coefficient which can be determined from the transmittance or absorbance in every wavelength based on Beer-Lambert law, $A$ is a constant, $n$ is a value was characterized by type of transition in the semiconductor materials. For direct transition, $n$ has a value of $1 / 2$, whereas for indirect transition $n=2$. It known that the $\mathrm{ZnO}$ is a direct transition semiconductor, so the $n$ value is $1 / 2$. Then, it can be plotted a curve between $(\alpha h v)^{2}$ with photon energy $(h v)$, usually called Tauc plot from which the band gap energy $\left(E_{g}\right)$ can be determined.

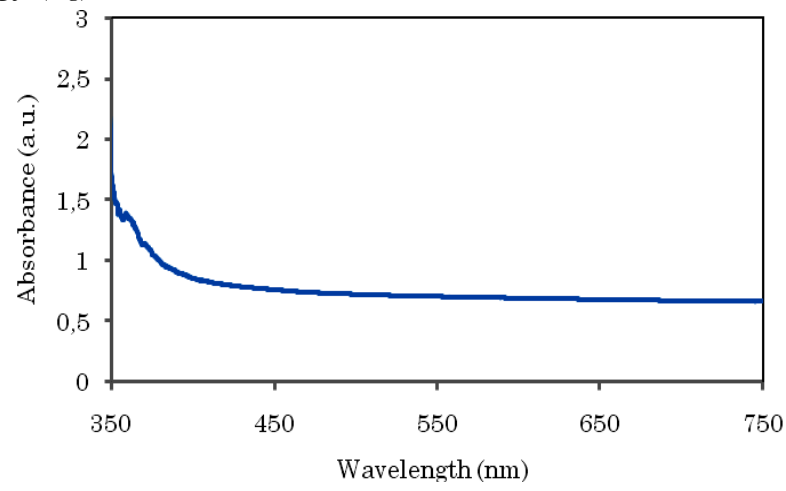

Fig. 3 - Absorption spectra of $\mathrm{ZnO}$ film

Fig. 4 shows a Tauc plot for the $\mathrm{ZnO}$ nanoparticle film. The plot shows an intercept the linear portion of graph to the photon energy $(h v)$ axis at about $3.2 \mathrm{eV}$, which is the optical bandgap value of $\mathrm{ZnO}$. This result closed to the results expressed by previous researchers who obtain a bandgap value of $\mathrm{ZnO}$ smaller than $3.3 \mathrm{eV}$ $[15,17]$.

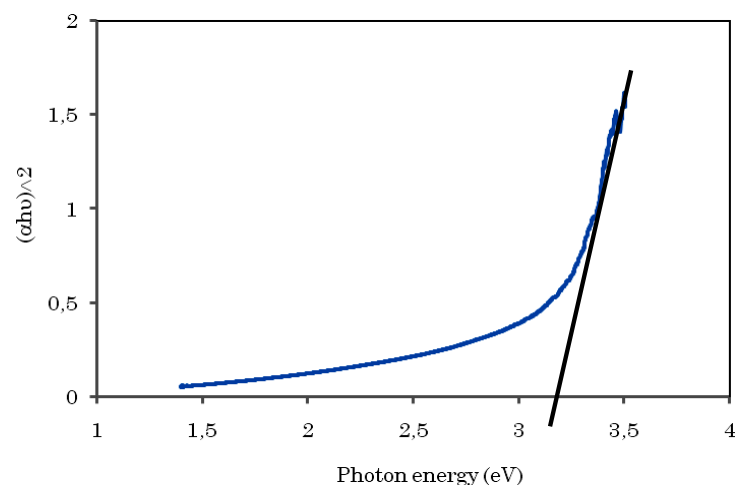

Fig. 4 - Optical bandgap of $\mathrm{ZnO}$ nanoparticle

\subsection{Optical Properties of Anthocyanin and ZnO/Antocyanin Hybrid Film}

Optical characteristics of anthocyanin dye extracted from Lampeni (Ardisia humilis Vahl) fruit was measured in the range of UV-Vis spectrum. Fig. 5 shows a wide range of absorption spectra of anthocyanin dye covering from $400 \mathrm{~nm}$ to $600 \mathrm{~nm}$, which suitable for application as sensitizer in dye-sensitized solar cell. Based on the absorption spectra, anthocyanin dye strongly absorbs electromagnetic wave around $550 \mathrm{~nm}$ which is the green spectrum.

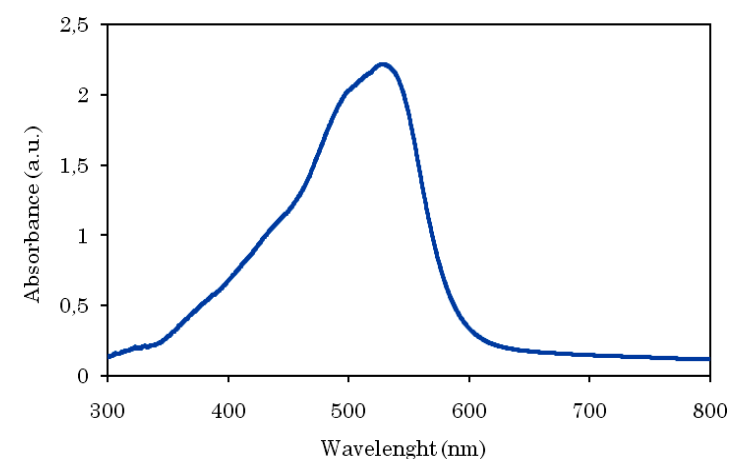

Fig. 5 - Absorption spectra of anthocyanin dye extrated from Lampeni (Ardisia humilis Vahl) fruit

Combination between $\mathrm{ZnO}$ nanoparticle and anthocyanin dye caused widening of absorption spectra, as can be seen at Fig. 6 . This widening show that numbers of spectrum absorbed increased after the combination. This combination also caused a change the color. This change was caused by the bond between dye chromophore from antocyanin with $\mathrm{Zn}$ (IIB) from $\mathrm{ZnO}$ where ion $\mathrm{OH}^{-}$from $\mathrm{Zn}$ (IIB) is bound with ion $\mathrm{H}^{+}$from antocyanin dye forms one molecule of $\mathrm{H}_{2} \mathrm{O}$. Adsorption on $\mathrm{ZnO}$ surface forms quinoidal which causes $\mathrm{ZnO}$ surface looks like violet and it only contains flavilium as for the red color. Characteristic peak of anthocyanin absorption spectra still exist, however shift to longer wavelenght at around $600 \mathrm{~nm}$. This fact indicates there are interactions between $\mathrm{ZnO}$ nanoparticles and anthocyanin dye. 


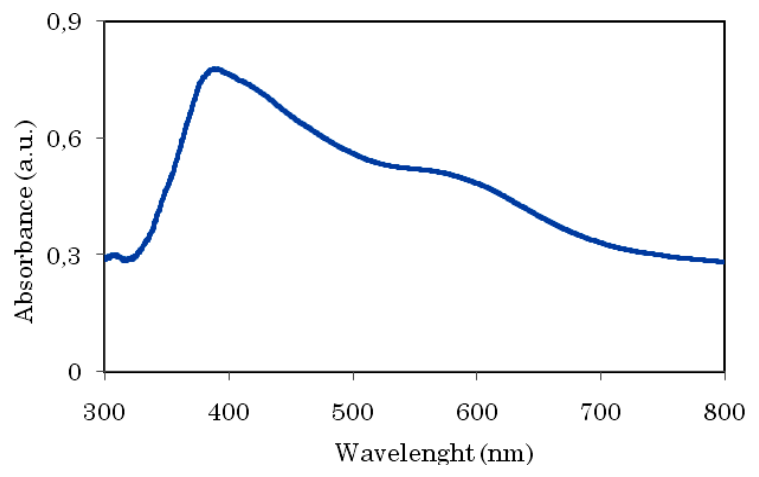

Fig. 6 - Absorption spectra of $\mathrm{ZnO} /$ anthocyanin hybrid film

\subsection{Performance of Solar Cell}

To know performance of the fabricated solar cell was carried out the measurement of voltage-current $(I-V)$ characteristic of solar cell. An I-V characteristic was measured directly under the sunlight. Fig. 7 shows the I-V graph of solar cell from where the parameters of

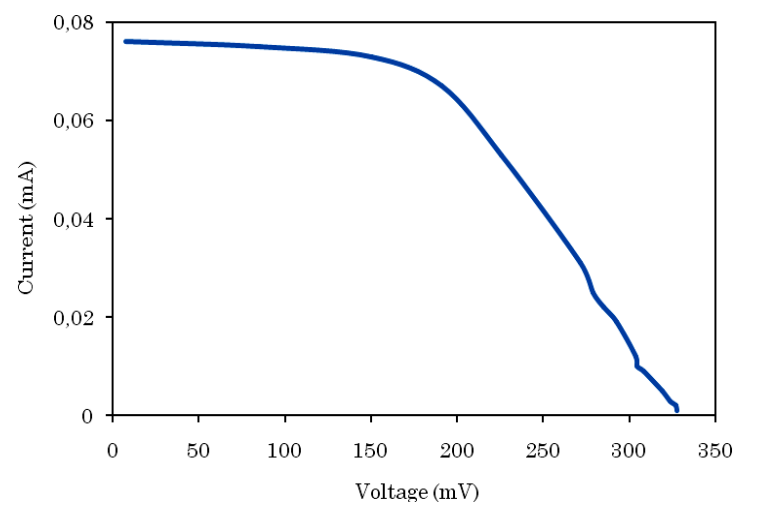

Fig. 7 - Current-voltage curve of solar cell

solar cell can be determined. The graph shows a more ideal I-V characteristic of solar cell diode, with fill factor 0.25 . The photocurrent generated is small caused by high resistance of $\mathrm{ZnO}$ semiconductor as photoanode layer in mega $\mathrm{Ohm}$ that became one of factors to contribute to the low performance of solar cells.

\section{REFERENCES}

1. M. Grätzel, Nature 414, 338 (2001).

2. R.C. Pawar, J.S. Shaikh, P.S. Shinde, P.S. Patil, Mater. Lett. 65, 2235 (2011).

3. A. Dumbrava, G. Prodan, A. Georgescu, F. Moscalu, Bull. Mater. Sci. 38 No 1, 65 (2015).

4. R. Gao, Z. Liang, J. Tian, Q. Zhang, L. Wang, G. Cao, Nano Energ. 2, 40 (2013).

5. D. Raoufi, T. Raoufi, Appl. Surf. Sci. 255, 5812 (2009).

6. S-F. Lee, Y-P. Chang, L-Y. Lee, J-F. Hsu, J. Eng. Technol. Educ. 5 No 4, 545 (2008).

7. R. Gao, Z. Liang, J. Tian, Q. Zhang, L. Wang, G. Cao, $R S C$ Adv. 3, 18537 (2013).

8. H. Zhitao, L. Sisi, L. Junjun, C. Jinkui, C. Yong, J. Semicond. 34 No 7, 074002 (2013).

9. I-D. Kim, J-M. Hong, B.H. Lee, D.Y. Kim, E-K. Jeon, D-
Parameters of the solar cell were summarized in Table 1. Open circuit voltage $\left(V_{o c}\right)$ resulted indicates the electrolyte $\mathrm{KI} / \mathrm{I}_{2}$ added into the cell works well. As well known that open circuit voltage $\left(V_{o c}\right)$ is diffrence between Fermi level of type- $n \mathrm{ZnO}$ semiconductor and chemical potential of electrolyte $\mathrm{KI} / \mathrm{I}_{2}$. From some research, it is known that adding electrolytes $\mathrm{KI} / \mathrm{I}_{2}$ can improve the performance of solar cells by increasing the open circuit voltage $\left(V_{o c}\right)$

Tabel 1 - Parameters of solar cell

\begin{tabular}{|c|c|c|c|c|c|c|c|}
\hline $\begin{array}{c}\text { Quanti- } \\
\text { ties }\end{array}$ & $V_{o c}(\mathrm{mV})$ & $\begin{array}{c}I_{s c} \\
(\mathrm{~mA})\end{array}$ & $\begin{array}{c}V_{\max } \\
(\mathrm{mV})\end{array}$ & $\begin{array}{c}I_{\max } \\
(\mathrm{mA})\end{array}$ & $\begin{array}{c}P_{\max } \\
(\mu \mathrm{W})\end{array}$ & $F F$ & $\eta(\%)$ \\
\hline Output & 342.8 & 0.15 & 191.1 & 0.06 & 12.80 & 0.25 & $3.3 \times 10^{-2}$ \\
\hline
\end{tabular}

However, the performance of the solar cell is still low. Conversion efficiency of the solar cell still low mainly due to the photocurrent output still extremely low. The maximum current $\left(I_{\max }\right)$ produced is still very small so that the output power is also small, so the overall efficiency is also low. This is caused by the process of electron transfer from the excited dye is not going smoothly to achieve in fotoanoda until only a few that can flow to the outside circuit, thus producing a small current.

\section{CONCLUSION}

Flower-like $\mathrm{ZnO}$ nanoparticle has been synthesized succesfully by precipitation method at low temperature and applied as photoanode in dye-sensitzed solar cell (DSSC) with anthocyanin dye as photosensitizer. The combination of $\mathrm{ZnO}$ nanoparticles and anthocyanin dye resulting optical absorption spectra experiencing widening in the visible range. It has been succeeded to make DSSC using $\mathrm{ZnO}$ as photoanode with anthocyanin dye from Lampeni (Ardisia humilis Vahl) fruit as dye sensitizer which can convert sunlight to electricity. It has been proved by the current and voltage generated from the DSSC. The voltage and current generated provides maximum power of $12.8 \mu \mathrm{W}$ with a conversion efficiency of $3.3 \times 10^{-2} \%$.
K. Choi, D-J. Yang, Appl. Phys. Lett. 91, 163109 (2007).

10. P. Murugakoothan, S. Ananth, P. Vivek, T. Arumanayagam, J. Nano-Electron. Phys. 6 No 1, 01003 (2014).

11. S. Ananth, P. Vivek, T. Arumanayagam, P. Murugakoothan, Spectrochim. Acta A 128, 420 (2014).

12. M.R. Narayan, Renew. Sust. Energ. Rev. 16, 208 (2012).

13. M.A. Ibrahem, W.H. Yu, M.H. Tsai, K.C. Ho, J.J. Shyue, C.W. Chu, Sol. Energ. Mater. Sol. C. 108, 156 (2013).

14. C. Bhakat, P.P. Singh, Int. J. Modern. Eng. Res. 2 No 4, 2452 (2012).

15. M.A. Shah, F.M. Al-Marzouki, Mater. Sci. Appl. 1, 77 (2010).

16. P.H. Park, S.W. Han, J. Nanosci. Nanotech. 7, 1 (2007).

17. S. Vishnoi, R. Kumar, S.P. Singh, B.P. Singh, Int. J. Nanotech. Appl. 3 No 4, 39 (2013). 